\title{
Analysis of The Influence of the Negative Electronic Word of Mouth and Its Effect on Repurchase Intention Mediated by Company Mitigation Responses
}

\author{
ENDWIEN HERSETYAWATI \\ Doctor of Research in Management Binus Business School \\ Binus University Jakarta Indonesia \\ J1. K. H. Syahdan No. 9, Kemanggisan, Palmerah,Jakarta, 11480, \\ INDONESIA
}

\author{
M ARIEF \\ Management Department, BINUS Business School Doctor of Research in Management, \\ Bina Nusantara University \\ J1. K. H. Syahdan No. 9, Kemanggisan, Palmerah,Jakarta, 11480, \\ INDONESIA \\ ASNAN FURINTO \\ Management Department, BINUS Business School Doctor of Research in Management, \\ Bina Nusantara University \\ Jl. K. H. Syahdan No. 9, Kemanggisan, Palmerah,Jakarta, 11480, \\ INDONESIA \\ HARDIJANTO SAROSO \\ Management Department, BINUS Business School Doctor of Research in Management, \\ Bina Nusantara University \\ Jl. K. H. Syahdan No. 9, Kemanggisan, Palmerah,Jakarta, 11480, \\ INDONESIA
}

\begin{abstract}
The purpose of this study was to determine the Negative Effect Of Electronic Word Of Mouth (NeWOM) on Repurchase Intention (RI) mediated by Company Mitigation Responses (CMR) on energy drinks products in Indonesia. This research method using quantitative research with the sampling technique in this study using a purposive random sampling technique. The sample obtained in this study amounted to 140 samples. The results showed that the negative variable brand experience sharing did not have a significant effect on negative electronic words of mouth, the negative variable electronic reviews had a significant effect on negative electronic words of mouth, and the negative variable electronic words of mouth had a significant effect on repurchase intentions, social variables. Networking has been shown to mediate the negative variable brand experience sharing on negative electronic word of mouth and the intensity variable use of social networking sites has also been shown to successfully mediate the effect of negative electronic reviews on negative electronic word of mouth. For further research, in order to be able to examine in a wider research context and in a larger sample of big cities. In addition, future research can embrace aspects related to other attributes of other branded products such as features, price, quality, and social attributes to provide greater insight into consumer behavior.
\end{abstract}

Key-Words: - Negative Electronic Words of Mouth, Company Mitigation Responses, Repurchase Intention, Energy Drink Received: March 13, 2021. Revised: July 12, 2021. Accepted: July 26, 2021. Published: August 4, 2021. 


\section{Introduction}

The internet has changed the way customers can express their dissatisfaction with the company and their ability to mobilize mass audiences against the company [1]. This suggests that customer complaints change, from the private realm to a public phenomenon [1]. Pontes [2] states that Social Networking Site (SNS) is one of the earliest and best examples for customers who take advantage of the new power offered by the Internet. For that reason, it can be concluded that SNS has intensified customer empowerment and their ability to complain to the world.

The emergence of web 2.0, often referred to as interactive web, offers consumers the opportunity to obtain information and to participate in word of mouth in the form of user-generated content [3]. Consumers no longer have to seek advice but prefer to engage with electronic word of mouth (eWOM) and take advantage of the very large number of user-generated products and product information available on SNS[4].

Given that NeWOM can inhibit the purchase behavior of the recipient, and thus has the potential to reduce the company's revenue [5]. Technological developments do not always have a good impact, various negative impacts also often appear along with the accelerating technological development. Many think that all the information that is spread on social networking sites (SNS) or the internet has become an important source of information for consumers because of the accessibility, speed and volume of information obtained.

A viral message circulating on SNS types of Facebook on June 192015 regarding a list of dangerous drinks that can trigger brain cancer, diabetes, and hardening of the spinal cord. The negative message was spread on behalf of Indonesian doctors, namely from Dr. Ismuhadi, MPH is the most viral post by an account on behalf of Gunawan Inkokusumo. This old message was redistributed by Facebook users. The negative message circulating about the list of dangerous drinks that trigger cancer is divided up to 105,459 times. The crux of the information claims that aspartame is contained by the beverage products on the list is a cause of hardening of the brain, diabetes, and hardening of the spinal cord. And the news prohibits the community from drinking energy drink products such as Ektra Joss, M-150, Krating Daeng, Hemaviton, Neo Hemaviton, Marinas, Segar Sari, Frutillo, Pop-Ice, Fresh Cold Vit C, Okky jelly drink, Inaco, Gatorade, vegetable, Adem Sari and many more.
This negative stigma is now a challenge that energy drink product manufacturers must face [6]. Although energy drink products that come out on the market have gone through very strict due diligence, and have also obtained certification from BPOM and halal from the Indonesian Ulama Council (MUI), even one company as a producer of energy drink products also has a machine to test haram ingredients. The production process of energy drinks is also processed in factories that have standards that have been given by the government, international standards to maintain product quality and production, have also standards for environmental management, even these products have content that is beneficial to the body such as Taurine, Caffeine, Inaitol, Vitamin B6, B12, B3 to Pro Vitamin B5, but the negative impact is very inherent and causes a decrease in the number of sales of energy drink products.

In Indonesia, the decline in sales of energy drink products in Indonesia reached $5.5 \%$, based on research conducted by Nielsen in 2019. Several energy drink products in Indonesia such as Extrajoss decreased by $8.3 \%$, Kuku Bima by $9.9 \%$, Hemaviton by $12.8 \%$, Ejuss at $65.5 \%$, and Proman at $88.8 \%$.

The downward trend in energy drink products in Indonesia arises from the negative stigma attached to the minds of consumers mentioned by Nielsen (2019) due to negative news spread on social networking sites (SNS) called negative electronic word of mouth (NeWOM) originating from negative brand experience sharing (NBES ) and negative electronic reviews (NER) so that company mitigation responses are needed to generate repurchase intention (RI) for energy drink products[7].

RI is the main construct to explain customer repurchase behavior. Based on research conducted by Arif, [8], it is explained that RI is a subjective probability that someone will buy products or services continuously from electronics suppliers or stores in the future. Lee et al., [9] research also explain that customers buy back behavior or intentions that are beneficial to the business. The increasing influence of electronic evaluation on electronic behavior has increased managerial interest and corporate research in recovery strategies that can reduce transmission of negative electronic word of mouth MA et al., [10]. This is especially important for marketers to understand the relatively recent shift in word of mouth.

The research of Wang and Mattila [11] also describes CMR such as explanation and apology, this explanation has an important role in NeWOM 
recovery which has an impact on consumer satisfaction and repurchase intention. The company's CMR significantly reduces the negative impact of NeWOM. Based on research from Yan, et al.,[12] states that evaluation of eWOM related to products and services through the social transmission process, several studies on company mitigation responses (CMR) on someone's emotional conveyance, the bond structure of the sender or the perceived similarity between the sender and the receiver.

The need for research on effective CMR strategies can influence future consumer behavior such as future repurchase intentions [13]. Previous studies agreed that five general results from NeWOM include dissatisfaction, complaints, switching to other products, negative messages, and stopping buying required efforts to increase consumer perception and increase consumer loyalty [14].

Craighead et al., [15] The majority of these studies concluded that he company must choose the appropriate remedy or risk terminating the purchase or subscription in the event of a service failure. Research has reported that when failures occur, customers are more likely to spread negative word of mouth (NWOM) and are unlikely to buy again [16]. Recovery efforts can have a positive effect on repurchase intentions [17]. Among those who question the effectiveness of recovery efforts, Tarofder et al., [18] argue that it is not necessary for all customers to continue to subscribe to the service despite recovery efforts. This may be due to substandard recovery efforts.

Based on the background of the above problems, this study seeks to review repurchase intention (RI), negative electronic word of mouth (NeWOM), which is mediated by company mitigation responses (CMR) on energy drink products in Indonesia.

\section{Problem Formulation}

Some negative news about the dangers of aspartame which causes brain cancer, diabetes, and hardening of the spinal cord are also spread by many social communities through electronic media, electronic communities, electronic customer reviews, SNS including WhatsApp groups, Facebook, electronic media, blogs. , and others.

Viral news about the dangers of aspartame content is very embedded in the minds of consumers, this is one of the causes of the continued decline in the energy drink market in Indonesia is the negative stigma that is already attached to the minds of consumers. Other stigmas include that energy drink products are not healthy, are considered as drinks for doping, are considered as opium so that consumers are addicted to consuming them. This negative stigma is now a challenge that must be faced by producers of energy drink products.

\section{Research Methods}

The design of this research starts from problem formulation, data collection, data processing to the preparation of research reports. This type of research used in this research is descriptive and verification. Descriptive research is used to obtain a systematic, actual and accurate description of the facts and characteristics of each variable studied, namely Negative Brand Experience Sharing (NBES), Negatives Electronic Reviews (NER), Negative electronic Word of Mouth (NeWOM), Company. Mitigation Responses (CMR), and Repurchase Intention (RI).

The sampling technique in this study using purposive random sampling technique is a sampling technique by paying attention to the considerations made by the researcher. So the researcher took the sample randomly but was determined by the researcher himself [19]. If the number of population members is between 101 and 500, 30-40\% of the sample can be taken. Based on this statement, this research will use a sample of $40 \%$ of the total population of this study, amounting to 350 people, so that the number of samples studied is 140 people.

The area of this research is limited to the energy drink business environment in Central Java. The selection of the Central Java region was chosen because the rate of decline was the highest compared to other regions in Indonesia, which was 74\% (Nielsen, 2019). These data indicate that the effect of NeWOM on RI has an impact on the decline in sales of energy drink products. The instrument used to collect data was a questionnaire which was identified using a Likert scale, where the alternative answers provided consisted of 5 choices, namely $\mathrm{SS}=$ strongly agree (5 points), $\mathrm{S}=$ agree (4 points), RR = doubt- doubt ( 3 points), $\mathrm{TS}=$ disagree (2 points), STS = strongly disagree (1 point).

This study uses data analysis methods using Smart PLS version 3.0.m3 software which runs on computer media. PLS (Partial Least Square) is a variant-based structural equation analysis (SEM) technique that can simultaneously test the measurement model as well as test the structural model. 


\section{Analysis and Discussion}

\subsection{Demographic Respondent}

Table 1. Characteristics of respondents in this study

\begin{tabular}{|c|c|c|}
\hline \multirow[t]{2}{*}{ Respondents } & \multicolumn{2}{|l|}{ Total } \\
\hline & Person & $\%$ \\
\hline \multicolumn{3}{|c|}{ Respondents by gender } \\
\hline - Men & 87 & $62,1 \%$ \\
\hline - Women & 53 & $37,9 \%$ \\
\hline \multicolumn{3}{|c|}{$\begin{array}{l}\text { Respondents by energy drink beverage } \\
\text { products }\end{array}$} \\
\hline - Kuku bima & 69 & $49,2 \%$ \\
\hline - $\quad$ Ekstra joss & 35 & $25 \%$ \\
\hline - Hemafiton & 30 & $21,4 \%$ \\
\hline - $\quad$ Proman & 7 & $5 \%$ \\
\hline \multicolumn{3}{|l|}{ Respondents by age } \\
\hline - 25-30 years & 77 & $55 \%$ \\
\hline - $30-35$ years & 39 & $27,8 \%$ \\
\hline - $35-40$ years & 24 & $17,1 \%$ \\
\hline \multicolumn{3}{|c|}{ Respondents based on education level } \\
\hline - $\operatorname{High}(\mathrm{D} 3, \mathrm{~S} 1)$ & 103 & $73,6 \%$ \\
\hline - $\mathrm{S} 2$ & 37 & $26,4 \%$ \\
\hline
\end{tabular}

Source: interview

Through Table 1, the characteristics of respondents seen from the demographic aspect, namely gender, age, education, and the choice of products purchased show some interesting information. Based on gender, the percentage of male respondents was $62.1 \%$ and for female respondents was $37.9 \%$ of the total sample size. Most of the respondents for the choice of products purchased Bima nails $49.2 \%$ of the total number of respondents, Extra joss by $25 \%$, Hemafiton by $21.4 \%$ and Proman by $5 \%$. Most of the respondents aged 25-30 years were 77 people with a percentage of $55 \%$ of the total number of respondents, while other respondents aged 30-35 years included 27.8\% and respondents aged 35-40 years covering $17.1 \%$. For education, most of them have a diploma level of education and S1 covers $73.6 \%$, S2 covers $26.4 \%$.

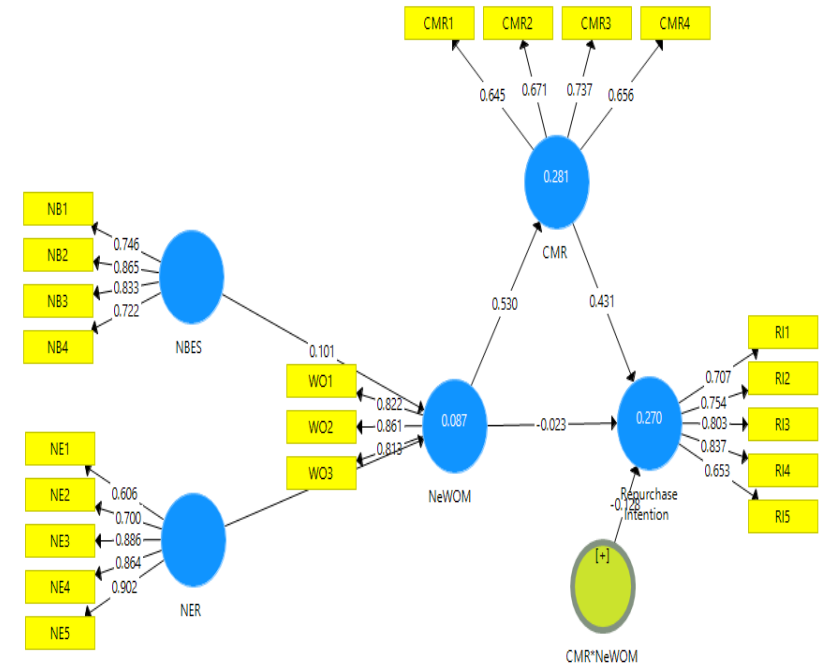

Fig.1: Theoretical Model Development Diagram

Validity testing is used to measure whether a research questionnaire is valid or not [20]. In other words, a measurement that has high reliability is able to provide reliable measurement results. Ghozali [29] states that a variable is declared reliable if it provides a Cronbach Alpha value greater than 0.60 .

Table 2. Cronbach Alpha

\begin{tabular}{|l|l|l|l|l|}
\hline & $\begin{array}{l}\text { Cronbach's } \\
\text { Alpha }\end{array}$ & rho_A & $\begin{array}{l}\text { Composite } \\
\text { Reliability }\end{array}$ & $\begin{array}{l}\text { Average } \\
\text { Variance } \\
\text { Extracted } \\
\text { (AVE) }\end{array}$ \\
\hline CMR & 0,608 & 0,606 & 0,772 & 0,559 \\
\hline NBES & 0,808 & 0,845 & 0,871 & 0,630 \\
\hline NER & 0,859 & 0,904 & 0,897 & 0,640 \\
\hline NeWOM & 0,787 & 0,811 & 0,871 & 0,692 \\
\hline $\begin{array}{l}\text { Repurchase } \\
\text { Intention }\end{array}$ & 0,817 & 0,852 & 0,867 & 0,568 \\
\hline
\end{tabular}

$\mathrm{Nb}$ : CMR (Company Mitigation Responses), NBES (Negative Brand Experience Sharing), NER (Negative Electronic Reviews), NeWOM (Negative Electronic Word of Mouth) and RI (Repurchase Intention)

Based on Table 2, the composite reliability test is obtained, the latent variable can be said to have good reliability if the composite reliability value is greater than 0.7. The Reliability test will test each latent variable reliability. Based on the table above, it is known that the CMR, NBES, NER, NeWOM, and Repurchase Intention variables have a reliability value of more than 0.7 so it can be said that all latent variables are reliable. Because the validity is sufficient, our model is declared to have reached the condition of convergence and the output of the outer loadings of all indicators meets the assumption of convergence validity. 
Table 3. Fornell-Larcker Criterion

\begin{tabular}{|l|c|c|r|l|l|}
\hline & NBES & NER & NeWOM & RI & CMR \\
\hline NBES & 0,827 & & & & \\
\hline NER & 0,549 & 0,675 & & & \\
\hline NeWOM & 0,162 & 0,280 & 0,802 & & \\
\hline RI & 0,702 & 0,637 & 0,231 & 0,849 & \\
\hline CMR & 0,512 & 0,564 & 0,371 & 0,350 & 0,688 \\
\hline
\end{tabular}

$\mathrm{Nb}$ : CMR (Company Mitigation Responses), NBES (Negative Brand Experience Sharing), NER (Negative Electronic Reviews), NeWOM (Negative Electronic Word of Mouth) and RI (Repurchase Intention)

In the Fornell-Larcker Criteria table 3. it can be seen that the $\sqrt{ }$ AVE value of the RI correlation variable is 0.849 . This value is greater than the correlation value of NBES, NER, NeWOM and CMR variables. This also applies to other variables, the $\sqrt{ }$ AVE value on the variable itself shows a higher number than the correlation between variables. Thus the discriminant validity requirement with $\sqrt{ } \mathrm{AVE}$ has been fulfilled.

\subsection{Structural Model Evaluation}

Based on the analysis results obtained $\mathrm{R} 1^{2}=0,281$, meaning that the latent negative variable electronic words of mouth can be explained well through electronic reviews and negative brand experience sharing) of $28.1 \% . \mathrm{R} 2^{2}=0,236$ means that the Repurchase Intention variable can be explained well through the negative latent electronic words of mouth and CMR) of $23.6 \%$.

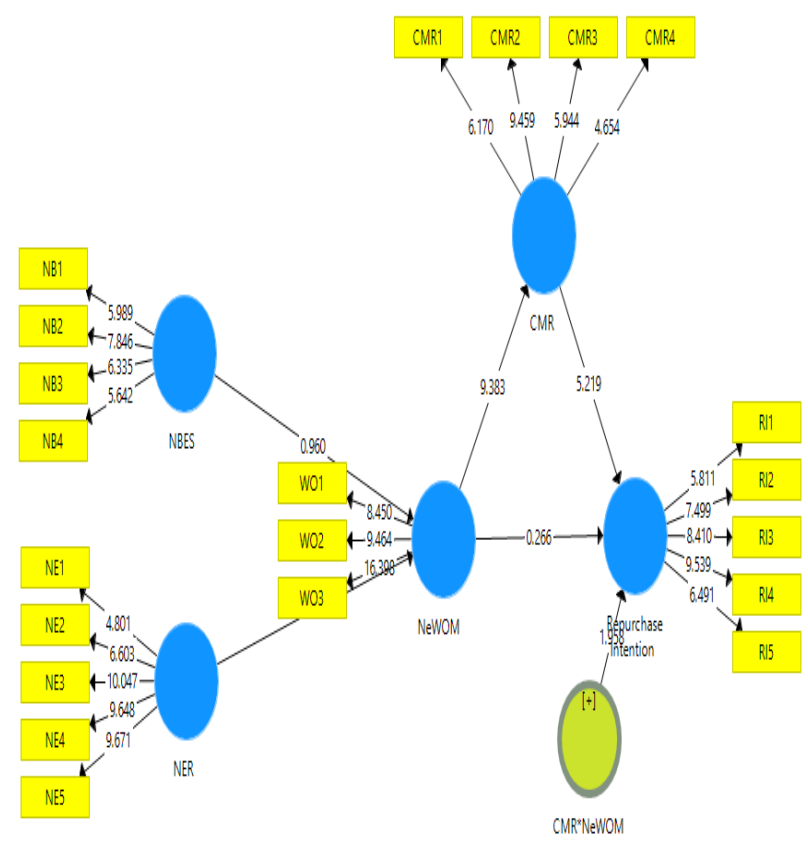

Fig.2: Theoretical Model Development Diagram
Table 4. $\mathrm{F}^{2}$. Test Results

\begin{tabular}{|l|l|l|}
\hline & $\mathrm{F}^{2}$ & $\begin{array}{l}\text { The magnitude } \\
\text { of the influence }\end{array}$ \\
\hline NBES --NeWOM & 0,011 & Less \\
\hline NBES -- CMR & 0,415 & Big \\
\hline NeWOM -- RI & 0,110 & Medium \\
\hline CMR -- NeWOM & 0,158 & Medium \\
\hline
\end{tabular}

Nb: CMR (Company Mitigation Responses), NBES (Negative Brand Experience Sharing), NER (Negative Electronic Reviews), NeWOM (Negative Electronic Word of Mouth) and RI (Repurchase Intention)

NBES (Negative Brand Experience Sharing) to NeWOM (Negative Electronic Word of Mouth) Less, NBES (Negative Brand Experience Sharing) to CMR (Company Mitigation Responses) Big, NeWOM (Negative Electronic Word of Mouth) to Repurchase Intention Medium and CMR (Company Mitigation Responses) to NeWOM (Negative Electronic Word of Mouth) Medium

\subsection{Hypothesis Test}

Before testing the hypothesis, a bootstrap procedure is carried out on the sample data. Bootstrapping was carried out 300 times where each bootstrap data was sampled back as many as 200 valid data. Bootstrap results with a bootstrap sample of 300 times it is assumed that the data is normally distributed so that testing of model parameters can be done using the $t$ test. The coefficient value of the structural model is said to be significant if the t-count> t-table is 1.96 (1.96 is the t-table value at the $95 \%$ confidence level).

The results of testing the outer model hypothesis concluded that all significant indicators were used to build the model while the results of the inner model hypothesis testing can be seen in Table 3 with the results of all significant path coefficients.

Table 5. T Test for Path Coefficients

\begin{tabular}{|l|l|l|l|l|l|}
\hline & $\begin{array}{l}\text { Original } \\
\text { Sample } \\
(\mathrm{O})\end{array}$ & $\begin{array}{l}\text { Sample } \\
\text { Mean } \\
(\mathrm{M})\end{array}$ & $\begin{array}{l}\text { Standard } \\
\text { Deviation } \\
\text { (STDEV) }\end{array}$ & $\begin{array}{l}\text { T } \\
\text { Stati } \\
\text { stics }\end{array}$ & $\begin{array}{l}\text { P } \\
\text { Values }\end{array}$ \\
\hline $\begin{array}{l}\text { CMR*Ne } \\
\text { WOM -> } \\
\begin{array}{l}\text { Repurchase } \\
\text { Intention }\end{array}\end{array}$ & $-0,128$ & $-0,118$ & 0,065 & 1,968 & 0,050 \\
\hline $\begin{array}{l}\text { NBES -> } \\
\text { NeWOM }\end{array}$ & 0,101 & 0,116 & 0,105 & 0,960 & 0,338 \\
\hline $\begin{array}{l}\text { NER -> } \\
\text { NeWOM }\end{array}$ & 0,230 & 0,239 & 0,118 & 1,949 & 0,050 \\
\hline $\begin{array}{l}\text { NeWOM - } \\
\text { Repurchase } \\
\text { Intention }\end{array}$ & 0,023 & $-0,014$ & 0,087 & 0,266 & 0,790 \\
\hline
\end{tabular}

Source: author 
Based on the table above, it is known that the negative variable brand experience sharing has no significant effect on negative electronic words of mouth with a $P$ value of 0,338 , the negative variable electronic reviews have a significant effect on the negative electronic words of mouth with a $\mathrm{P}$ value of 0,050 , the negative variable electronic word of Mouth has no significant effect on repurchase intention with a $\mathrm{P}$ value of 0,790 .

\subsection{Discussion}

Negative variable brand experience sharing has no significant effect on negative electronic words of mouth (t statistic $0.960<1.96$ and value 0.338 ). This means that the negative variable brand experience sharing does not have a significant effect on the negative variable electronic word of mouth. The results of this study are in accordance with the results of research conducted by Chu, et al.,[21]which states that not all consumers receive negative electronic words of mouth, if consumers do not want to receive the message received, the resulting impact of the message also there will be no negative impact even though they have been exposed to messages from negative electronic words of mouth. The negative behavior of electronic words of mouth refers to communication between consumers where consumers exchange productrelated marketing information [22],[23]. As for the negative impact of electronic word of mouth, such as being able to form negative attitudes from individuals, the emergence of negative brand experience sharing attitudes on product use, switching to other products and reducing the intention to repurchase a product which of course will in the end have a negative impact on the company.

The negative variable electronic reviews has a significant effect on negative electronic words of mouth (t statistic 1.949> 1.96 and a value of 0.050 ). This means that the negative variable brand experience sharing has a significant effect on the negative variable electronic word of mouth. This means that the negative electronic review variable has a significant effect on the negative variable electronic word of mouth. The results of this study are in accordance with the results of research conducted by Chirumalla et al [24], saying that companies must immediately respond positively to negative reviews submitted by consumers electronically in order to create an atmosphere of good marketing relations between consumers and companies. In addition, companies must respond quickly and make efforts to respond to these negatives rather than ignoring negative reviews from consumers which of course will have a negative impact on the company's survival (business survival)[25]. It can be interpreted that companies that do not respond to negative electronic reviews from consumers directly can put the company in an unfavorable position, because the company may eventually lose consumers in the future [23]. Demmers [26] say that complaints and negative experiences can be communicated and spread quickly and instantly in a large network to other people (firestorm).

The negative variable electronic word of mouth has no significant effect on repurchase intention $(\mathrm{t}$ statistic $0.266<1.96$ and value 0.790 ). This means that the negative brand experience sharing variable does not have a significant effect on the repurchase intention variable. The results of this study are inconsistent with the results of research conducted by Liang et al., [28], who say that the negative brand experience sharing variable has a significant effect on repurchase intention. Consuming energy drink products can be considered a habit because of its repetitive nature every day that is automatically done accidentally. In this case, consumer behavior that is often done before is an important determinant of behavior that will be carried out in the future which can make sales of energy drink products positive and increase for the sustainability of the company's business (survival business)[28].

Based on the test results of the structural equation modeling parameter, the critical ratio value is $1.968 \geq 1.96$ with a significance probability value of $0.050 \leq \alpha$ significance of 0.05 . It can be interpreted that the company mitigation responses variable can moderate the negative electronic words of mouth variable on repurchase intentention. The results of this study are consistent with the results of research conducted by Li et al., [29], Herhausen et al, [30]. which states that the variable company mitigation responses can moderate negative electronic words of mouth on repurchase intention, either directly or indirectly. Managing negative electronics words of mouth as a marketing instrument and influencing how communication between consumers to produce positive purchasing decisions is a very difficult task [31]; Keiningham [32], have investigated the drivers of negative electronic words of mouth and their impact on sales, consumer decision-making processes and consumer attitudes towards a product. 


\section{Conclusions and Suggestions}

\subsection{Conclusion}

Based on the analysis and discussion above, it can be concluded that:

Based on the results of the analysis and discussion, it can be concluded that the negative variable brand experience sharing has no significant effect on negative electronic words of mouth, the negative variable electronic reviews has a significant effect on the negative electronic words of mouth, the negative variable electronic words of mouth has a significant effect on repurchase intention. social variables Intensity of using network sites has been shown to mediate the negative variable sharing brand experiences on negative electronic word of mouth and the intensity variable use of social networking sites has also been shown to successfully mediate the effect of negative electronic reviews on negative electronic word of mouth .

Based on the results of the analysis and discussion, it can be concluded that the negative variable brand experience sharing has no significant effect on the negative variable electronic word of mouth, the negative variable brand experience sharing has a significant effect on the negative variable electronic word of mouth, the negative variable brand experience sharing has no significant effect. significant to the repurchase intention variable and that the company mitigation responses variable can moderate the negative electronic words of mouth variable on repurchase intentention.

The implications of this research are as a trigger for clearer direction regarding the measurement of the company mitigation responses variable. As seen in previous research, there are still many gaps and inconsistencies in drawing reference benchmarks from company mitigation responses which are considered increasingly complex in certain industries. This research shows that the company's mitigation responses from the energy drink product industry.

\subsection{Research Suggestions}

The internet has changed the way customers can express their dissatisfaction with companies and their ability to mobilize mass audiences against. The development of information technology makes electronic word of mouth the most popular source for obtaining reliable information and can influence consumers in the decision-making process to buy a product. In addition, the specific influence of negative reviews should also be of concern to the company.
When consumers experience negative experiences, companies usually offer something in the form of compensation to restore the situation such as providing an explanation or apology which can have a positive impact on consumer satisfaction and the intention to buy back the product. Efforts to restore the unpleasant impression experienced by consumers are very important in maintaining consumer feelings about the negative experiences they have experienced.

This study is useful for managers in determining behavior and actions in assessing the performance of the company to find the efforts made in dealing with the negative impact of negative electronic word of mouth on repurchase intention for the company's business continuity.

\subsection{Further Research}

This research on company mitigation responses in this study was conducted in the energy drink product industry. For further research, in order to be able to examine in a wider research context and in a larger sample of big cities. In addition, future research can embrace aspects related to other attributes of other branded products such as features, price, quality, and social attributes to provide greater insight into consumer behavior.

\section{References:}

[1] Orthaber, Sara. "Aggressive humour as a means of voicing customer dissatisfaction and creating in-group identity." Journal of Pragmatics, Vol. 152, 2019,p. 160-171.

[2] Pontes, Halley M., Megan Taylor, and Vasileios Stavropoulos. "Beyond "Facebook addiction": The role of cognitive-related factors and psychiatric distress in social networking site addiction." Cyberpsychology, Behavior, and Social Networking, Vol. 21, No. 4,2018, p. 240-247.

[3] Kang, Ju-Young M. "Showrooming, webrooming, and user-generated content creation in the omnichannel era." Journal of Internet Commerce, Vol. 17, No. 2, 2018, p. 145-169.

[4] Liu, Hongfei, et al. "Social sharing of consumption emotion in electronic word of mouth (eWOM): A cross-media perspective." Journal of Business Research, Vol. 132, 2021, p. 208-220.

[5] Tran, Gina A., and David Strutton. "Comparing email and SNS users: Investigating e-servicescape, customer reviews, trust, loyalty and E-WOM." Journal 
of Retailing and Consumer Services, Vol. 53, 2020, p.101782.

[6] Geiger-Oneto, Stephanie, Betsy D. Gelb, and Travis Simkins. "Stigmatized products: how conflicting laws can influence decisions to proceed." Journal of Business Strategy, Vol. 42 No. 1, 2021, p. 41-49.

[7] Yang, Albert Jing-Fuh, Shih-Hao Wu, and Pei-Yu Wu. "An empirical investigation of the factors influencing online repurchase intention: evidence from the hotel industry." International Journal of Agriculture Innovation, Technology and Globalisation, Vol. 1, No. 2, 2019, p. 114-127.

[8] Arif, Moh Erfan. "The influence of electronic word of mouth (EWOM), brand image, and price on re-purchase intention of airline customers." Jurnal Aplikasi Manajemen, Vol. 17, No. 2, 2019, p. 345-356.

[9] Mohamud, Suad Sheikh, et al. "Investigating The Antecedents of Coffee Shop Customers'behavioral Intentions In Kuala Lumpur." International Journal on Recent Trends in Business and Tourism (IJRTBT), Vol. 1, No.4, 2017, p. 1-14.

[10] Ma, Liye, Baohong Sun, and Sunder Kekre. "The Squeaky Wheel Gets the Grease-An empirical analysis of customer voice and firm intervention on Twitter." Marketing Science, Vol. 34, No. 5, 2015, p. 627-645.

[11] Wang, Chen- ya, and Anna S. Mattila. "A cross- cultural comparison of perceived informational fairness with service failure explanations." Journal of services marketing , Vol. 25. No. 6, 2011, p. 429-439

[12] Yan, Qiang, Shuang Wu, Lingli Wang, Pengfei Wu, Hejie Chen, and Guohong Wei. "E-WOM from e-commerce websites and social media: Which will consumers adopt?." Electronic Commerce Research and Applications, Vol. 17, 2016, p. 62-73.

[13] Kim, Kawon, and Melissa A. Baker. "Paying it forward: The influence of other customer service recovery on future cocreation." Journal of Business Research, Vol. 121, 2020, p. 604-615.

[14] Wang, Yang, and Alexander Chaudhry. "When and how managers' responses to online reviews affect subsequent reviews." Journal of Marketing Research, Vol 55, No. 2, 2018, p. 163-177.

[15] Wang, Xuhui, and Qilin Zhang. "Does online service failure matter to offline customer loyalty in the integrated multi-channel context? The moderating effect of brand strength." Journal of Service Theory and Practice, Vol. 28, No. 6, 2018, p. 774-806. https://doi.org/10.1108/JSTP-01-2018-0013

[16] Wilson, Andrew E., Michael D. Giebelhausen, and Michael K. Brady. "Negative word of mouth can be a positive for consumers connected to the brand." Journal of the Academy of Marketing Science, Vol 45, No. 4, 2017, p. 534-547.

[17] Mende, Martin, et al. "Service robots rising: How humanoid robots influence service experiences and elicit compensatory consumer responses." Journal of Marketing Research, Vol 56, No 4, 2019, p. 535-556.

[18] Tarofder, Arun Kumar, Seyed Rajab Nikhashemi, SM Ferdous Azam, Prashantini Selvantharan, and Ahasanul Haque. "The mediating influence of service failure explanation on customer repurchase intention through customers satisfaction." International Journal of Quality and Service Sciences, 2016.

[19] Sharma, Gaganpreet. "Pros and cons of different sampling techniques." International journal of applied research. Vol 3, No 7, 2017, p. 749-752.

[20] Mohajan, Haradhan Kumar. "Two criteria for good measurements in research: Validity and reliability." Annals of Spiru Haret University. Economic Series, Vol 17, No 4, 2017, p. 5982.

[21] Chu, Shu-Chuan, and Juran Kim. "The current state of knowledge on electronic word-of-mouth in advertising research." International Journal of Advertising, Vol 37, No 1, 2018, p. 1-13.

[22] Mahapatra, Sabita, and Abhishek Mishra. "Acceptance and forwarding of electronic word of mouth." Marketing Intelligence \& Planning, Vol. 35, No. 5, 2017, p. 594-610. https://doi.org/10.1108/MIP-01-2017-0007

[23] Zhou, Zhimin, Ge Zhan, and Nan Zhou. "How does negative experience sharing influence happiness in online brand community? A dual-path model." Internet Research, Vol. 30 No. 2, 2019, p. 575-590. https://doi.org/10.1108/INTR-12-2018-0531

[24] Chirumalla, Koteshwar, Pejvak Oghazi, and Vinit Parida. "Social media engagement strategy: Investigation of marketing and R\&D interfaces in manufacturing industry." Industrial Marketing Management, Vol 74, 2018, p.138-149. 
[25] Ali, Ubedullah Amjad, Tariq Jalees, and Sahar Qabool. "Extending the Theory of Reasoned Action on Antecedents to Consumer Repurchase Intentions." Market Forces, Vol 13, No 2,2018, p. 115-133

[26] Demmers, Joris, Willemijn M. Van Dolen, and Jesse WJ Weltevreden. "Handling consumer messages on social networking sites: customer service or privacy infringement?." International Journal of Electronic Commerce, Vol 22, No 1, 2018, p. 8-35.

[27] Liang, Lena Jingen, HS Chris Choi, and Marion Joppe. "Understanding repurchase intention of Airbnb consumers: perceived authenticity, electronic word-of-mouth, and price sensitivity." Journal of Travel \& Tourism Marketing,Vol 35, No. 1, 2018, p. 73-89.

[28] Bonn, Mark A., J. Joseph Cronin Jr, and Meehee Cho. "Do environmental sustainable practices of organic wine suppliers affect consumers' behavioral intentions? The moderating role of trust." Cornell Hospitality Quarterly, Vol 57, No 1, 2016, p. 21-37.

[29] Li, Xiaofei, Baolong Ma, and Rubing Bai. "Do you respond sincerely? How sellers' responses to online reviews affect customer relationship and repurchase intention." Frontiers of Business Research in China, Vol 14, No 1, 2020, p. 1-13.

[30] Herhausen, Dennis, Stephan Ludwig, Dhruv Grewal, Jochen Wulf, and Marcus Schoegel. "Detecting, preventing, and mitigating online firestorms in brand communities." Journal of Marketing, Vol 83, No. 3, 2019, p. 1-21.

[31] Von Helversen, Bettina, et al. "Influence of consumer reviews on online purchasing decisions in older and younger adults." Decision Support Systems, Vol 113, 2018, p. 1-10.

[32] Keiningham, Timothy Lee, et al. "A roadmap for driving customer word-ofmouth." Journal of Service Management, Vol. 29 No. 1, 2018, p. 2-38. https://doi.org/10.1108/JOSM-03-2017-0077

\section{Contribution of individual authors to the creation of a scientific article (ghostwriting policy)}

\section{Author Contributions:}

Endwien Hersetyawati is the main author of this article and also plays a role in analyzing the statistical data generated in this study.

M Arief is an expert in the field of research management, he is very helpful in providing input and input in this research so that it can produce quality research.

Asnan Furinto is an expert in the field of research management, he is also an expert in the field of e-commerce so that he is very instrumental in providing input on the use of theories in this research in order to produce quality research.

Hardijanto Saroso is an expert in strategic management, industrial benchmarking, management technology, and E-Business. he plays a role in providing input and input in this research so that it can produce quality research.

Sources of funding for research presented in a scientific article or scientific article itself

All funding in this study came from private funding.

Creative Commons Attribution License 4.0 (Attribution 4.0 International, CC BY 4.0)

This article is published under the terms of the Creative Commons Attribution License 4.0 https://creativecommons.org/licenses/by/4.0/dee d.en_US 